\title{
Gastric Cancer pN2 TNM Finding v6
}

National Cancer Institute

\section{Source}

National Cancer Institute. Gastric Cancer pN2 TNM Finding v6. NCI Thesaurus. Code C61194.

Gastric cancer with evidence of metastasis in 7-15 regional lymph nodes. (from AJCC 6th Ed.) 